\title{
Impact of Corrosive Substances on the Mucosa of the Digestive Tract
}

\author{
RODICA DANIELA BIRLA ${ }^{1 *}$, PETRE ANGEL HOARA ${ }^{1}$, VALERIU-GABI DINCA ${ }^{2}$, \\ ALEXANDRA-LIGIA DINCA ${ }^{3}$, SILVIU CONSTANTINOIU ${ }^{1}$ \\ ${ }^{1}$ Carol Davila University Bucharest, Faculty of Medicine, 8 Eroii Sanitari, 050474, Bucharest, Romania \\ ${ }^{2}$ Titu Maiorescu University Bucharest, Faculty of Medicine, 22 Dambovnicului Str., 040441, Bucharest, Romania \\ ${ }^{3}$ Medicover Hospital Bucharest, 24 Preciziei, 062202, Bucharest, Romania
}

Caustic ingestion is a major health concern in both developed and developing countries, that may lead to serious esophageal and gastric injury.Initially, the ingestion of a caustic substance produces postcaustic esophagitis, this being the acute phase, which in time by chronicization and by the methods of tissue remodeling, by fibrosis determines the post-caustic esophageal stenosis.

Key words:caustic ingestion, esophageal lesions, gastric injury

Ingestion of caustic substances often leads to severe morbidity and, frequently, death. Eymologic, the term corrosive is used for the action of acidic substances on the tissues and for the effect of the alkaline substances the term caustic is used. Currently, for both types of substances the term caustic is used [1].

For a long time, many authors agreed that the acids cause more damage to the gastric mucosa, whereas alkalis have a tendency for greater damage to the esophageal mucosa [2]. $[3,4]$.

However, it is now known that these agents cause mucosal injuries in both the organs with no selective preference

The symptomatology differs depending on the digestive segment predominantly affected. Thus, if the patient has dysphonia, dyspnoea then the lesion is in the epiglottis and larynx and represents a medical emergency that endangers the patient's life, causing acute respiratory failure [3]. If the corrosive substance has particularly damaged the esophagus, then the main symptoms of the patient are dysphagia and odynophagia. Stomach involvement causes epigastric pain or hematemesis $[5,6]$.

Caustic agents can be acidic or alkaline in nature. Common alkali-containing caustic agents are household bleaches, drain openers, toilet bowel cleaners, dishwashing agents and detergents. Strong alkalis sold in liquid and granular forms are the principal causes of severe damage. Household bleach, dishwasher detergents, and other cleaning agents, all of which are mildly alkaline, are the most common caustic substances ingested. Alkalis commonly used are hydroxides of sodium and potassium. Acidic agents, frequently responsible, are the ones that are commonly available such as cleaning agents (hydrochloric acid) and a gold solvent, which is a mixture of hydrochloric and nitric acid (aqua regia) [7].

Alkaline substances are tasteless, colorless, odorless and have a viscous consistency, so their ingestion tends to be mostly accidental and in large quantities. [8] The most commonly used alkaline substance is sodium hydroxide.

The acids have a pungent odor and an unpleasant taste, which is why the amount of the substance ingested is small and most often suicidal. The slightly alkaline $p \mathrm{H}$ of the saliva buffers the acidity of the substance, thus the lesions being milder in the esophagus. [1].

Acid-containing agents implicated in caustic ingestion include toilet bowl cleaners, anti-rust compound, swimming pool cleaners, vinegar, formic acid used in the rubber tanning industry and other similar acids $[9,10]$.

The type of caustic agent most commonly implicated in poisonings varies from country to country. In a report, the most commonly implicated caustic agent was the alkali-sodium hypochlorite, which was found in bleaches, toilet bowl cleaners, drain cleaners and household disinfectants. Local experiences from some contries - Denmark, Israel, United Kingdom, Peru, Spain, Australia, Saudi Arabia and Turkey also showed that alkaline agents were more commonly involved in caustic injury[10].

Indian data, on the other hand, showed that majority of ingestions in their country were due to acids since these were cheaper and more readily available[9,10].

Some authors reported that bleach seems to constitute approximately $30 \%$ of all caustic substances ingested by children; drain or grease cleaners make up 30\% of the total and various acid or alkali cleaners and detergents such as oven, toilet, tile, and drain cleaners, lye solvents, and battery acids make up 40\% [11-13].

*email:gaby_uk30@yahoo.com 
Such caustic substances are particularly dangerous because they are transparent (like water) and are sold as generic grease cleaners in open transparent bottles (especially $500 \mathrm{ml}$ water containers) that can be easily accessed by children in developing countries [14].

Overall, the corrosive injuries of the upper GI tract are more often seen in the developing countries $[15,16]$.

According to the American Association of Poison Control (AAPCC) since 2000, approximately 200,000 cases of ingestion of substances used in cleaning have been reported [17].

The literature describes 2 age groups prone to ingestion of caustic substances. In the first group, children between the ages of 1-5 years are framed, which are prone to accidental ingestion, compared to the second group, in which adolescents and adults who are prone to ingesting causal substances for suicidal purpose are framed. [18]

Corrosive injuries of the GI tract are seen in accidental or suicidal intake of acids or alkalis. Accidental intake is more commonly seen in children, whereas the suicidal intent is the usual cause in adults $[5,10,19]$.

Almost all ingestions by children are accidental; the intention is usually to drink water $(82 \%)[14,20]$. However, it is difficult to accept that caustic ingestion accidents in developing countries are truly accidental, as they in fact reflect extreme negligence. In addition, caustic substances are sometimes accidentally given to babies by their mothers, grandmothers, or babysitters [14].

Most parents have low incomes and are poorly educated (mother, 88-96\%; father, 62-80\%) [14]. A study found that children ingesting caustic substances were more impulsive than others; hyperactivity was also recognized as a risk factor in children younger than 5 years [21].

In adults caustic ingestion is usually a deliberate suicide attempt [22]; this attempt is rare $(0-0.6 \%)$ in children $[14,20,21]$.

Another studies have shown that caustic ingestions occur more often in boys (57-64\%), in children of a mean age of 3 years, mostly in summer (38.1\%) and spring (31.7\%), mostly in the family home, and usually in the kitchen $(51.5 \%)[23,21]$.

Most caustic substances were ingested in the liquid form and events commonly occurred at home[10]. Some authors noted that, a considerable number $(22-23 \%)$ of accidentally caustic ingestion occur during family visits (thus in the homes of grandparents and relatives) [20, 24].

The caustic substances are mostly liquids sold in nonoriginal containers (69-93\%), particularly transparent water bottles $(38 \%)$, which are often $500 \mathrm{ml}$ bottles or plastic carbonated-drink bottles (23\%) lacking both warning labels $(72-83 \%)$ and childproof safety caps $(83-93 \%)[14,20]$.

\section{Pathology}

Caustic agents can damage any segment of the gastrointestinal tract. However, the most commonly lesions of the upper gastrointestinal tract are in the oropharynx, larynx, esophagus, and stomach [25].

However, the injuries are usually limited to the oro-oesophageal mucosa, and do not feature massive necrosis or stricture development. The physical form and especially the $\mathrm{pH}$ of caustic substances are important for the oesophageal damage; $\mathrm{pH}$ values more than 12 and less than 1.5 are associated with massive caustic injuries [8].

The severity of the injuries caused by the corrosive substances is due to the accumulation of factors: the concentration of the corrosive substance, the $\mathrm{pH}$ of the agent, the quantity of the ingested substance and the duration of the contact between the caustic substance and the affected tissues [5,6]. The oesophagus is the organ most commonly affected after caustic ingestion. Injuries due to caustics can be restricted to the esophagus or stomach. Coexistent esophageal and gastric injuries are seen in $20 \%-62.5 \%$ cases [26,27].

Crystalline drain cleaners (including concentrated sodium hydroxide) are strong alkalis and especially affects the proximal oesophagus, injury to which is extremely dangerous. Highly concentrated, caustic alkaline liquids usually pass quickly through the oropharynx and cause extremely severe injuries to the oesophagus $[28,29]$.

In contrast, strong acids are bitter and are commonly expectorated. However, if swallowed, such acids quickly pass through the oesophagus and cause enormous damage to the gastric antrum, particularly if the stomach is empty. The duodenum and intestine are protected, to some extent, by pylorospasm [30]. The mucosa is damaged within seconds of contact with strong alkali or acid. Injuries caused by alkaline and acidic agents differ greatly [31].

The mechanism of acidic and alkaline injury is coagulation necrosis and liquefactive necrosis, respectively.Acid ingestion triggers coagulation necrosis of the mucosa, and formation of hard eschars usually associated with limited penetration into the mucosa [32].

In contrast, ingested alkali penetrates tissue and induces liquefactive necrosis, followed by destruction of the epithelium and submucosa and commonly extension into and sometimes through all muscle layers. Ischemia and thrombosis are early features. Then, a friable discolored eschar develops, under which tissue damage continues until the alkali is neutralized. Injuries to the oesophagus are evident principally at the three zones of constriction: the cricopharyngeal area (in the upper region); the mid- oesophagus at the point of crossing of the aortic arch and the left main bronchus (in the middle region); and immediately above the oesophago-gastric junction (in the lower region) [4].

Hemorrhage, thrombosis, and marked inflammation with edema develop in the first $24 \mathrm{~h}$ after injury. Depending on 
the extent of burning, the inflammation may extend through the muscle layer until perforation occurs. If the injury is transmural, the necrosis may extend to the surrounding mediastinum, initiated mediastinitis. If the injury extends anteriorly, trachea-oesophageal or even aorto-oesophageal fistulae may appear.After $48 \mathrm{~h}$, submucosal vessels develop thromboses, with local necrosis and gangrene. Bacterial contamination leads to the development of small intramural abscesses, which may extend to the mediastinum of full-thickness injuries. Several days later, the necrotic tissue sloughs, the edema is reduced, and neovascularization begins. Collagen deposits are seen beyond 2 weeks. This early reparative (or subacute) phase develops from the end of the first week and throughout the second week after injury. Scar formation begins in the third week, when fibroblasts proliferate to replace the submucosa and the muscularis, and stricture formation starts.

Then, mucosal re-epithelialization develops, and is usually complete by the sixth week. Adhesions may form during this period, narrowing or obliterating the oesophageal lumen. The end result may be a fibrotic stricture and a shortened oesophagus, induce gastro-oesophageal reflux and a motility disorder [20, 33].

The esophageal layer involved in fibrosis is determined by the depth of injury caused by the caustic substance. Oesophageal dysmotility may persist for several weeks, or may even become permanent if muscle is replaced by fibrous tissue [34]. Clinically significant gastric injury is relatively uncommon in children. Gastric outlet obstruction and pyloric stenosis are the most frequently gastric complications reported after caustic ingestion [35]. Gastric perforation is very rare. The transit time from the mouth to the stomach of acids is shorter than that of alkalis. Thus, although alkalis cause more severe esophageal injuries, acidic substances are associated with gastric injuries. The severity of gastric injury is determined by the amount and $p \mathrm{H}$ of the caustic substance ingested, and stomach fullness at the time of ingestion [36, 37].

\section{Conclusions}

Caustic ingestion remains a major health problem, especially in developing countries, where legislation is not very strict regarding the handling of caustic substances. The incidence of these accidents continues to be unacceptably high if the caustic substances were to be sold only in the original containers. It is important to reveal the need for preventive education programs for children and adults.

\section{References}

1.C.N. NEACŞU, C. PLEŞA, D. VINTILĂ, PAULA POPA, N. DĂNILĂ - Aspecte clinice şi terapeutice în esofagitele acute postcaustice. Jurnalul de Chirurgie, Iasi, 2007, Vol. 3, Nr. 2 [ISSN 1584 -9341]

2.LAHOTI D, BROOR SL. Corrosive injury to the upper gastrointestinal tract. Indian J Gastroenterol. 1993;12:135, 41. [PubMed] [Google

Scholar]

3.NAGI B, KOCHHAR R, THAPA BR, SINGH K. Radiological spectrum of late sequelae of corrosive injury to upper gastrointestinal tract.

A pictorial review. Acta Radiol. 2004;45:7-12. [PubMed] [Google Scholar]

4.ZARGAR SA, KOCHHAR R, NAGI B, MEHTA S, MEHTA SK. Ingestion of corrosive acids: Spectrum of injury to upper gastrointestinal tract and natural history. Gastroenterology. 1989;97:702-7. [PubMed] [Google Scholar]

5.CONTINI S, SCARPIGNATO C. Caustic injury of the upper gastrointestinal tract: a comprehensive review. World J Gastroenterol 2013; 19: 3918-3930 [PMID: 23840136 DOI: 10.3748/wjg.v19.i25.3918]

6.PARK KS. Evaluation and management of caustic injuries from ingestion of Acid or alkaline substances. Clin Endosc 2014; 47: 301-307 [PMID: 25133115 DOI: 10.5946/ce.2014.47.4.301]

7.ANANTHAKRISHNAN N, PARTHASARATHY G, KATE V. Chronic corrosive injuries of the stomach-a single unit experience of 109 patients over thirty years. World J Surg. 2010;34:758-64. [PubMed] [Google Scholar]

8.CHIBISHEV A, SIMONOVSKA N, SHIKOLE A. Post-corrosive injuries of upper gastrointestinal tract. Prilozi 2010; 31: 297-316 [PMID: 20693948]

9.SATAR S, TOPAL M, KOZACI N. Ingestion of caustic substances by adults. Am J Ther. 2004;11:258-261. [PubMed] [Google Scholar] 10.LAKSHMI CP, VIJAYAHARI R, KATE V, ANANTHAKRISHNAN N. A hospital-based epidemiological study of corrosive alimentary injuries with particular reference to the Indian experience. Natl Med J India. 2013;26:31-36. [PubMed] [Google Scholar] 11.DOGAN Y, ERKAN T, COKUGRAS FC, ET AL. Caustic gastroesophageal lesions in childhood: an analysis of 473 cases. Clin Pediatr (Phila) 2006; 45:435-438.

12.GUN F, ABBASOGLU L, CELIK A, ET AL. Early and late term management in caustic ingestion in children: a 16-year experience. Acta Chir Belg 2007; 107:49-52.

13.BOSKOVIC A, STANKOVIC I. Predictability of gastroesophageal caustic injury from clinical findings: is endoscopy mandatory in children? Eur J Gastroenterol Hepatol 2014; 26:499-503.

14.UYGUN I, AYDOGDU B, OKUR MH, ET AL. Clinico-epidemiological study of caustic substance ingestion accidents in children in Anatolia: the DROOL score as a new prognostic tool. Acta Chir Belg 2012; 112:346-354

15.ANANTHAKRISHNAN N, PARTHASARATHY G, KATE V. Acute corrosive injuries of the stomach: A single unit experience of thirty years. ISNR Gastroenterol. 2011;2011:914013. [PMC free article] [PubMed] [Google Scholar]

16.RAMASAMY K, GUMASTE VV. Corrosive ingestion in adults. J Clin Gastroenterol. 2003;37:119-24. [PubMed] [Google Scholar] 17.BRONSTEIN AC, SPYKER DA, CANTILENA LR, GREEN J, RUMACK BH, HEARD SE. 2006 Annual Report of the American Association of Poison Control Centers' National Poison Data System (NPDS). Clin Toxicol(Phila) 2007; 45: 815-917 [PMID: 18163234 DOI: $10.1080 / 15563650701754763$ ]

18.LUPA M, MAGNE J, GUARISCO JL, AMEDEE R. Update on the diagnosis and treatment of caustic ingestion. Ochsner J 2009; 9: 54-59 [PMID: 21603414]

19.GUMASTE VV, DAVE PB. Ingestion of corrosive substances by adults. Am J Gastroenterol. 1992;87:1-5. [PubMed] [Google Scholar] 20.SANCHEZ-RAMIREZ CA, LARROSA-HARO A, VASQUEZ-GARIBAY EM, ET AL. Sociodemographic factors associated with caustic substance ingestion in children and adolescents. Int J Pediatr Otorhinolaryngol 2012; 76:253-256.

21.CAKMAK M, GOLLU G, BOYBEYI O, ET AL. Cognitive and behavioral characteristics of children with caustic ingestion. J Pediatr Surg Rev. Chim. $71 \bullet$ no. $2 \bullet 2020 \diamond$ https://revistadechimie.ro 
22.POLEY JW, STEYERBERG EW, KUIPERS EJ, ET AL. Ingestion of acid and alkaline agents: outcome and prognostic value of early upper endoscopy. Gastrointest Endosc 2004; 60:372-377

23.URGANCI N, USTA M, KALYONCU D, ET AL. Corrosive substance ingestion in children. Indian J Pediatr 2014; 81:675-679. This is a retrospective single center large case series (1709 cases) in children who ingested corrosive substance confirming previous information.

24.OTHMAN N, KENDRICK D. Epidemiology of burn injuries in the East Mediterranean region: a systematic review. BMC Public Health $2010 ; 10: 83$

25.KLUGER Y, ISHAY OB, SARTELLI M, KATZ A, ANSALONI A, GOMEZ CA, ET AL. Caustic ingestion management: World society of emergency surgery preliminary survey of expert opinion. World J Emerg Surg. 2015;10:48. [PMC free article] [PubMed] [Google Scholar]

26.POSTLETHWAIT RW. CHEMICAL BURNS OF THE ESOPHAGUS. Surg Clin North Am. 1983;63:915-24. [PubMed] [Google Scholar] 27.MEENA BL, NARAYAN KS, GOYAL G, SULTANIA S, NIJHAWAN S. Corrosive injuries of the upper gastrointestinal tract. J Dig Endosc. 2017;8:165-9. [Google Scholar] 28.TOVAR R, LEIKIN JB. Irritants and corrosives. Emerg Med Clin North Am 2015; 33:117- 131.

29.MILLAR AJ, COX SG. Caustic injury of the oesophagus. Pediatr Surg Int 2015; 31:111-121.

30.OZOKUTAN BH, CEYLAN H, ERTASKIN I, ET AL. Pediatric gastric outlet obstruction following corrosive ingestion. Pediatr Surg Int 2010; 26:615-618.

31.MOORE WR. Caustic ingestions. Pathophysiology, diagnosis, and treatment. Clin Pediatr (Phila) 1986; 25:192-196.

32.OZCAN C, ERGUN O, SEN T, ET AL. Gastric outlet obstruction secondary to acid ingestion in children. J Pediatr Surg 2004; 39:1651 1653.

33.MEENA BL, NARAYAN KS, GOYAL G, SULTANIA S, NIJHAWAN S. Corrosive injuries of the upper gastrointestinal tract. J Dig Endosc. 2017;8:165-9. [Google Scholar]

34.CADRANEL S, DI LORENZO C, RODESCH P, ET AL. Caustic ingestion and esophageal function. J Pediatr Gastroenterol Nutr 1990; 10:164-168.

35.TEMIZ A, OGUZKURT P, EZER SS, ET AL. Management of pyloric stricture in children:endoscopic balloon dilatation and surgery. Surg Endosc 2012; 26:1903-1908.

36.CEYLAN H, OZOKUTAN BH, GUNDUZ F, ET AL. Gastric perforation after corrosive ingestion. Pediatr Surg Int 2011; 27:649-653. 37.LUPU V.V., IGNAT A., PADURARU G., CIUBARA A., IONUC A., CIUBARA A.B., GHEONEA C., BURLEA M. - The study of effects regarding ingestion of corrosive substances in children - Rev.Chim., 67, no. 12, 2016, p.2501

$\overline{\text { Manuscript received: } 30.10 .2019}$ 
